\title{
'Weak-Center' Gentrification and the Contradictions of Containment: Deconcentrating Poverty in Downtown Los Angeles
}

\author{
ELLEN REESE, GEOFFREY DEVERTEUIL and \\ LEANNE THACH
}

\begin{abstract}
This case study of recent efforts to deconcentrate poverty within the Skid Row area of Los Angeles examines processes of 'weak-center' gentrification as it applies to a 'service dependent ghetto,' thus filling two key gaps in prior scholarship. We document the collaboration between the government, business and development interests, and certain non-profit agencies in this process and identify two key mechanisms of poverty deconcentration: housing/service displacement and the criminalization of low income residents. Following Harvey, we argue that these efforts are driven by pressures to find a 'spatial fix' for capital accumulation through Downtown redevelopment. This process has been hotly contested, however, illustrating the strength of counter-pressures to gentrification/poverty deconcentration within 'weak-center' urban areas.
\end{abstract}

\section{Introduction}

During the 1970s and 1980s, the incidence of poverty in America hardly increased, but it became far more spatially concentrated, resulting in the greater likelihood that poor people would contend with even more limited opportunities (Wilson, 1987). By the early 1990s, fears of such purported ill effects contributed to the rise of the deconcentration of poverty as the dominant policy response to urban inequality in most American cities. This shift involves public policies that explicitly disperse zones of extreme poverty particularly in inner-city areas - by encouraging the inclusion of higher-income groups and housing subsidies (Wyly and Hammel, 1999; Crump, 2002). The most prominent strategy includes the wholesale demolition of high-rise public housing, followed by mixed-income developments (Hackworth, 2003; Hammel, 2006; Wilson, 2006). These authors (and others) point to a strong connection between poverty deconcentration and gentrification, in which the former clearly precedes, and is part of, a broader statesubsidized and globalized strategy to remake cities along higher-class lines (Smith, 2002).

We wish to contribute to a better understanding of the nexus between poverty deconcentration and gentrification by addressing two key gaps. First, we focus on the political struggles over efforts to deconcentrate poverty in a much less prominent zone of 
concentrated poverty - not public housing, but rather the 'service-dependent ghetto,' where the homeless, discharged psychiatric patients, parolees and other marginalized populations are concentrated in close proximity to services and cheap housing (Dear and Wolch, 1987). Second, we wish to explore deconcentration efforts within a context of what we term 'weak-center' gentrification, that is, within cities that lack strong or high-amenity downtowns to act as centers of gravity for anchoring gentrification. Particularly in the American Sunbelt, urbanization tends to be low-density, car-oriented and overwhelmingly suburban in nature, as well as decidedly polycentric, producing a lack of a well-defined center that would conceivably produce an upward class transformation.

In this article, we are interested in addressing both of these empirical gaps through a case study of recent efforts to deconcentrate, if not dismantle entirely, the largest service-dependent ghetto still in existence in the USA - Skid Row in Downtown Los Angeles - and resistance to this process within a context of weak-center gentrification across the Los Angeles region. We begin by discussing the poverty deconcentration/ gentrification nexus, returning to the two aforementioned empirical gaps. Second, we outline our methodological approach, followed by a discussion of the context of homelessness in Los Angeles County. Third, we briefly present the past 20 years of struggles over policies towards the homeless in Skid Row, Los Angeles. In the 1970s, policy-makers adopted the policy of containing the homeless in the Skid Row area through a combination of service concentration and selective police enforcement of public nuisance laws. This policy, adopted as a way to appease both Downtown developers and advocates of the poor, sowed the seeds for later conflicts over efforts to disperse the poor when the homeless population rose amid growing interest in expanding redevelopment projects. We pay special attention to the central and symbiotic role of government and private agents (e.g. real estate developers, business owners, police, and certain non-profit agencies) within these processes of containing and later displacing the poor. Following Harvey (1982; 1985a; 1985b), we argue that these rounds of Downtown investment and contrasting efforts to control the territoriality of the poor were primarily driven by pressures to find a 'spatial fix' for capital accumulation. The context of a 'weak center' city, however, has fostered considerable resistance to efforts to deconcentrate the poor, both from the poor and their allies concentrated within Skid Row, and from capital and middle class residents within outlying areas.

\section{Deconcentrating urban poverty and gentrification}

In order to bring the nexus between poverty deconcentration and gentrification to the foreground, we must briefly examine the larger context in which these dynamics operate. Peck and Tickell (2002) have identified a new, more intensive 'roll-out' phase of neoliberalism in which social policy incursions are increasingly tied to crisis displacement, deferral, and management (see also Jessop, 2002). Populations excluded by earlier rounds of neoliberalism and the hollowing-out of the welfare state - the poor, unemployed, welfare recipients, immigrants, and low-skilled laborers - are now subject to greater state authoritarianism and an increasingly punitive re-regulation. Re-regulation is begetting a more interventionist local state, one engaged in the simultaneously linked agenda of image-building while also enforcing greater social control over marginalized populations (Peck, 2001), or what Smith (2002: 80) calls a 'new revanchist urbanism'. Recent waves of urban gentrification involve both intensified partnerships between local governments and private capital and authoritarian policies to contain and repress the poor. The implementation of 'zero tolerance' policies towards crime tends to target poor racial minorities; it is a reactionary 'social cleansing strategy' that attempts to reassert 'traditional decency,' thereby facilitating the urban revitalization process (Smith, 2002; Wyly and Hammel, 2005). Similarly, efforts to police public spaces in the USA have 
been on the rise, including the criminalization of homelessness through the adoption and enforcement of various ordinances, such as bans on sleeping or urinating on public sidewalks (Mitchell, 2003; National Law Center on Homelessness and Poverty, 2006). Faced with intense inter-urban competition, many local states feel obligated to follow suit, although the actual impacts upon a very tenacious homeless population have perhaps been more uneven and ambivalent than the current 'revanchist' literature has portrayed (DeVerteuil, 2006; DeVerteuil et al., 2009).

One policy direction that epitomizes many of the interventionist and strategically partnered tendencies of roll-out neoliberalism is the aggressive effort to deconcentrate zones of extreme poverty. Beginning in the early 1990s, the federal government sought to reinvent public housing through the HOPE VI (Housing Opportunities for People Everywhere) program. This program funded the demolition of public housing, its dispersion, and/or efforts at income mixing. While uneven in its impacts across various cities, the program became a cornerstone of 1990s neoliberal urbanism and an important initial tool to help 'turn around' entire inner-city neighborhoods for their eventual upgrading (Wyly and Hammel, 1999; Hackworth, 2003; Hammel, 2006). Certain cities, such as Chicago, have drastically reduced their public housing stock, tearing down large housing projects such as Cabrini-Green and the Robert Taylor Homes to lay the groundwork for mixed-use residences. Gentrification has become a systematic privatepublic urban strategy at the forefront of a globalized neoliberal and market-oriented urbanism (Smith, 2002) that encompasses a wide range of upgrading techniques, including poverty deconcentration and 'social mixing' (Newman and Wyly, 2006).

David Harvey's concept of 'spatial fix' is particularly useful for understanding the underlying forces behind gentrification and poverty deconcentration. Harvey (1982) argues that capitalists frequently seek 'spatial fixes' in order to stave off, at least temporarily, crises associated with the overaccumulation and devaluation of capital. The crisis of overaccumulation refers to 'an excess of capital in relation to the opportunities to employ that capital profitably,' which can take the form of money, commodities, or productive capacity. In the absence of a spatial fix, this crisis is resolved through the devaluation of capital, which leads to falling rates of profit, declining prices, idle equipment or physical infrastructures, or falling real wages. Harvey (2001 [1981]) originally used his concept of 'spatial fix' to explain such macro-level processes as imperialism and international trade and investments. Yet, Harvey (1985a: 226) argues that 'superior command over space,' vital to the survival of capitalism, occurs both within urban regions as well as across nations.

Here, we sharpen our analysis by articulating the concept of 'spatial fix' to explain movements of capital into areas of concentrated urban poverty within Los Angeles and the pressures underlying efforts to contain or disperse the poor. As Harvey (1985b) suggests, struggles over the built environment involve various distinct fractions of capital, including landlords, developers, financial capital, construction companies and other types of businesses. Concentrated poverty, which tends to agglomerate alongside the concentration of capital, threatens the interests of capital by potentially reducing the return on their investment in that area. It encourages social unrest, threatening to depreciate the value of current or future investments in real estate, businesses and other aspects of the built environment. As Harvey (1982: 233-34) argues, the built environment is a 'geographically ordered, complex, composite commodity' in which the 'usefulness of individual elements [of the built environment] depends, to a large degree upon the usefulness of surrounding elements' (ibid.). Similarly, he argues that, 'specific sites can command a premium land rent precisely because of their privileged location relative to previous investments', especially those considered the most desirable by those with the most income and capital - and their distance from other undesirable elements. Harvey (1985b: 68) contends that the capacity to express their class interests and shape public policy is critical for speculative developers and landlords seeking to maximize their investment returns or rent, just as it is for business owners seeking to maximize their profits. 
Drawing on these insights, we argue that policies of poverty deconcentration (or containment) tend to serve the interests of various fractions of capital invested in a particular area, even as it threatens the interests of capital invested elsewhere. Such state interventions, which seek to control and discipline the poor and their command of space, are important mechanisms for transforming social landscapes and making viable 'spatial fixes' for the crises of overaccumulation. These strategies are both shaped by, and help to shape, the territoriality of social infrastructures, including the placement of police officers, homeless shelters, and other social services for the poor. The capacity to carry out policies of poverty deconcentration and containment frequently engender resistance, both from the poor and their allies, as well as fractions of capital and middle class residents located elsewhere. Indeed, struggles over the geographic configuration of poverty are dynamic processes shaped by many contradictory forces, including economies of scale, 'not in my backyard' (NIMBYism), profit incentives to invest where land is cheap, 'law and order' interests, trends in public and private funding, and the organized advocacy on behalf of low-income people, middle class residents, business owners, and investors. Just as relocating capital at one point in time drives the search for subsequent 'spatial fixes' for capital accumulation (Harvey, 1985a), poverty deconcentration primarily induces displacement and dispersion of the 'problem' rather than solves it (Newman and Wyly, 2006; Slater, 2006a, 2006b).

While otherwise insightful, the literature addressing the poverty deconcentration/ gentrification nexus may be accused of being rather narrowly focused on just a few 'typical' cases and suffering from at least two blind spots. First, little work has examined poverty zones beyond public housing, such as the 'service-dependent ghetto' (Dear and Wolch, 1987). Perhaps one reason why the reconfiguration of the latter has been ignored is due to the fact that their demise was seemingly sealed back in the 1980s, when many 'Skid Rows' were in fact dismantled (Goetz, 1992; Wolch and Dear, 1993). Census data reveals an increasing decentralization of the homeless population away from downtown areas since the $1950 \mathrm{~s}$, creating a polynucleated pattern in most cities. With the revitalization of central business districts, including the implementation and enforcement of new anti-homeless ordinances and the relocation of services for homeless people, these trends accelerated in the 1990s (Lee and Price-Spratlen, 2004: 20).

A second gap is the examination of the nexus within a distinctive and divergent context for gentrification, what we term 'weak-center' gentrification. Many newer cities in the American Sunbelt lack strong or high-amenity downtowns to act as centers of gravity for anchoring the process of gentrification, instead featuring strongly polycentric patterns. This runs against the 'strong-center', more monocentric patterns found in older, more established cities such as New York, Chicago, Toronto, Boston and San Francisco, where the vast majority of studies of gentrification are located and where the process of poverty deconcentration has been sharper and more longstanding. In such strong-center cities, the vigorous demand to live near the central business district (CBD) has spurred the upgrading of proximate neighborhoods for those priced out of the closest markets. In a polycentric city with a weak center, however, this process is highly uneven and somewhat muted for the region as a whole, since there is less (or perhaps even no) need for higher classes to live near the CBD, or that there is no dominant CBD at all (i.e. Phoenix); rather, mass suburbanization is the dominant urban process. As a result, polycentric urban regions with weak CBDs, such as Los Angeles and Houston, have seen their inner-city areas devalue since the 1970s, contrary to the gentrifying experience of strong-CBD urban regions like New York, San Francisco, Washington, Chicago and Boston (Hackworth, 2005). At the very least, the concept of 'weak-center' gentrification challenges the notion of the more inner-city focused, monocentric and strong-center urban pattern - and considers the possibility that urban form can be a potential barrier to rampant gentrification - and by association, poverty deconcentration (see Shaw, 2005 for other barriers).

Let us briefly apply this concept to a particular setting: the Los Angeles urban region. Given its size and high profile among urbanists, it seems strange that Los Angeles has in 
fact been decidedly overlooked by the gentrification literature. ${ }^{1}$ With the exception of Davis (1990) and Keil (1998), most serious researchers of Los Angeles have little to say about central-city commercial/residential upgrading and poverty deconcentration, perhaps because - to the so-called 'LA School' - the periphery organizes the center, which is the complete opposite of gentrification dynamics found in places like New York and Chicago (Soja, 2000) and perhaps because gentrification seems so weak versus pervasive suburbanization (Hannigan, 1995). Nevertheless, gentrification has emerged in various pockets throughout Los Angeles (e.g. Santa Monica, Venice, Hollywood, Silverlake and Echo Park) even though no one center, not even Downtown Los Angeles, exerts anything more than a weak gravitational pull on the entire urban region. Downtown Los Angeles holds 5\% of total employment for Los Angeles County (10 million people) and with fewer residents than the downtowns of smaller cities such as Vancouver and Philadelphia. For these reasons, studying gentrification in Los Angeles should provide an interesting counterpoint to the currently dominant evidence from strongly-centered urban regions.

\section{Data and methods}

As George (1979) and Burawoy (1991) suggest, the aim of case studies should not be simply to illustrate or test existing theory, but to reconstruct and further refine it by addressing theoretical gaps, make sense of anomalies or 'negative cases' that are inconsistent with theoretical expectations and identify new causal patterns. Here, we seek to address the processes through which the deconcentration of the 'service dependent ghetto' is being carried out within a 'weak-centered' city, Los Angeles, the combination of which has been under-theorized in the urban studies literature.

From September 2004 until January 2007, we conducted ground-level research on homelessness and revitalization in Downtown Los Angeles, focusing on newspaper archives, websites, and interviews. We collected material predominantly from the period 1998 to 2007, during which sustained efforts to deconcentrate Skid Row emerged. We identified relevant articles, using internet search engines such as Lexis Nexis and Proquest. We examined articles from major newspapers, such as Los Angeles Times, as well as from local papers such as Downtown News (pro-business) and Community Connection (the Los Angeles Community Action Network's newsletter). Both Government and private websites were used as sources for journals, reports, and press releases. The unpublished one-year evaluation of the Safer City Initiative by Blasi et al. (2007) was particularly useful as it provided information on the design and cost of this policy and its impacts on the numbers of criminal citations in the Skid Row area as well as recent shifts in sentencing policies affecting residents of this area.

Interviews were conducted by telephone, email and in person with key staff members. The sample of 15 interviewees focused on important agents of both change and resistance, including representatives from the Central City East Association (CCEA) a local business association, the Downtown Women's Center, the Los Angeles Community Action Network (LACAN), the Los Angeles Homeless Services Authority, the National Coalition for the Homeless and the Los Angeles Coalition to End Hunger and Homelessness. The sample also included a precinct captain and a police officer employed with the Los Angeles Police Department, the Downtown Neighborhood Prosecutor and Gary Blasi (Law Professor at UCLA). The interviewees were asked 5-10 open-ended questions during interviews ranging from 20-90 minutes in length, which were transcribed and analyzed. In addition, we periodically consulted with a

1 As of September 2008, a keyword search in Sociological Abstracts on 'gentrification' and 'Los Angeles' revealed only two journal articles. 
videographer, Ernest R. Savage IIII, who was producing a documentary of struggles over Skid Row in order to keep ourselves updated about the events unfolding there.

\section{Context: homelessness in Los Angeles and Skid Row}

Los Angeles County is the homeless capital of the USA, with at least 88,000 homeless in 2005 (LAHSA, 2006). These numbers are sustained by a lack of living-wage employment, declining to non-existent welfare support and a severe deficit in affordable housing which accelerated in the 2000s and pushed many people into homelessness (Wolch and Dear, 1993; DeVerteuil, 2005). As of 2006, fair market rent for a studio (no-bedroom) apartment in Los Angeles-Long Beach metropolitan area was US \$843 per month, well beyond the monthly rent affordable to a minimum-wage earner (US \$351) or a recipient of Supplemental Security Income (US \$251) (National Low Income Housing Coalition, 2006). ${ }^{2}$ In 2006, average rents were US $\$ 1,750$ a month, $82 \%$ more than a decade ago, while the city lost a total of 9,000 rent-controlled apartments between the start of 2005 and the end of 2006 (Cleeland, 2006).

Although dispersed throughout the County, the largest concentrations of homeless individuals are found in older, heterogeneous inner-city neighborhoods where homeless services tend to cluster in 'service hubs' (DeVerteuil, 2006). By far the largest of these hubs is Skid Row, where a disproportionate array of shelters, single-room occupancy (SRO) hotels, drop-ins and substance abuse treatment are concentrated. In 2000, this 50 -square block area held an astonishing $25 \%$ of all the County's shelter beds - over 13,000 in total (Goetz, 1992; Keil, 1998; CCA, 2002; DeVerteuil, 2006). Although new shelters have been built in more suburban locales, Skid Row remains by far the largest clustering of homeless services and people in LA County - a tempting target for poverty deconcentration. The Skid Row homeless population is particularly vulnerable. It is predominantly composed of African-Americans, who confront both contemporary racism and the accumulated disadvantages associated with past racism. Because services for low-income people are concentrated in the area, the rates of mental disabilities and substance abuse are also about twice as high among the homeless in Skid Row compared to the entire County. All of these factors are exacerbated by an unwillingness to tackle homelessness in a coordinated, well-funded approach, especially when compared to some other American metropoli - for example New York or Portland, Oregon (Blasi et al., 2007; Wolch, 2008).

\section{The historical development of Skid Row}

Skid Row is situated at the eastern edge of Downtown Los Angeles (see Figure 1). Today's Downtown shelters were originally developed in the 1900s to assist those who came to Los Angeles to find work and settle down. Commercial hotels that used to serve a 'transient but working population' eventually became converted into long-term housing for low-income people (Spivack, 1998: 5). Containing the homeless in the Skid Row area began in 1976 as an official city policy, admidst a boom in commercial development of Downtown Los Angeles (Keil, 1998; Rymer, 2001). The policy, which aimed to stabilize the provision of low-income housing, particularly SRO hotels and social services in the Skid Row area represented a compromise between Downtown investors and some public officials who sought to increase land values by displacing the homeless population away from Downtown redevelopment projects - and advocates of the homeless, who sought to protect the homeless and increase their access to shelter space and services (Goetz, 1992; Rymer, 2001). The policy of containment was largely orchestrated by the

2 The US Department of Housing and Urban Development estimates that monthly rent should be no more than $30 \%$ of your income to be affordable. 


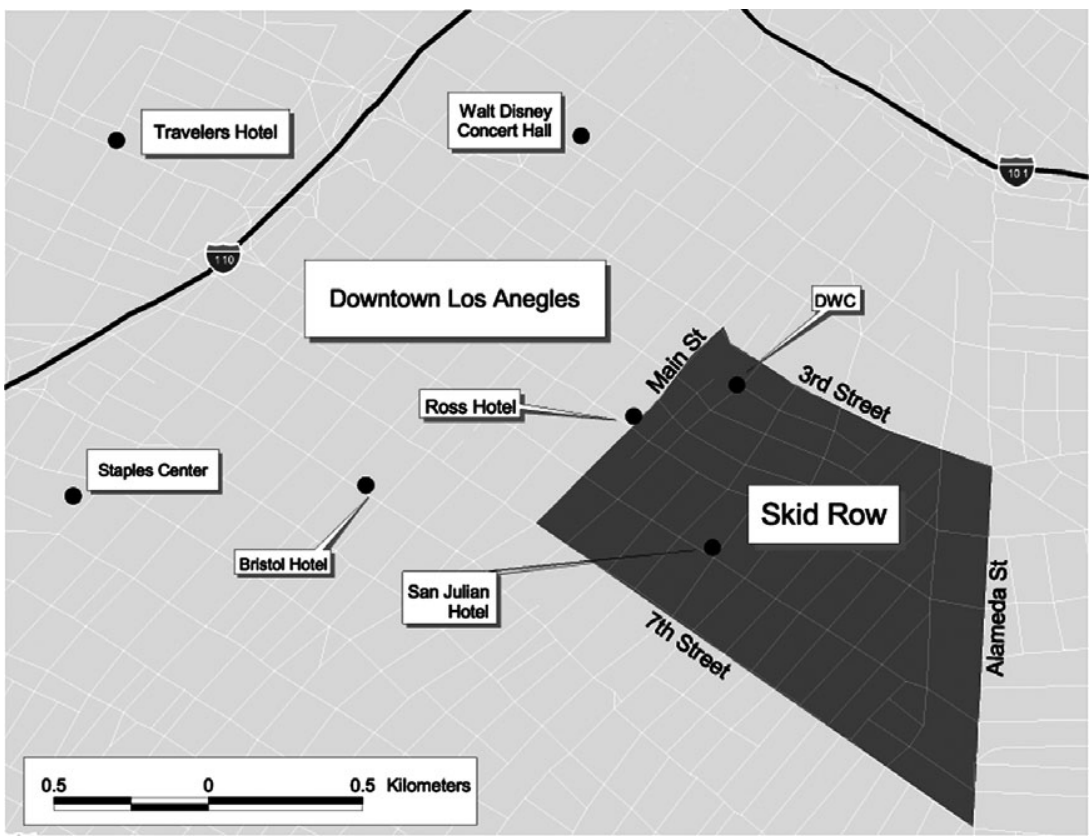

Figure 1 Locator map of Skid Row, Los Angeles

Community Redevelopment Agency (CRA), which sought to create a '24-hour downtown rivaling any world class city' (Goetz, 1992: 544), but which agreed to maintain affordable housing for the poor and services for the homeless in response to public pressure. To rehabilitate and maintain the buildings and provide affordable housing, the CRA established the SRO Housing Corporation in the 1980s. The city also concentrated all social services into one area in order to meet the needs of the local population (Goetz, 1992; Spivack, 1998; Rymer, 2001). The policy of containment thus appeased Downtown investors' search for a 'spatial fix' for capital accumulation amid a burgeoning homeless population, as well as public officials' interest in maintaining legitimacy amid rising accusations of their neglect of the poor.

By selectively enforcing the law, the LAPD helped to keep the homeless isolated within the Skid Row area and out of the redeveloping office core. Containment helped to protect the interests of large corporates which were invested in other Downtown areas, but infuriated the Central City East Association (CCEA), representing smaller and less powerful businesses (such as fish-processing plants and toy manufacturers) located in the Skid Row area. The CCEA sought unsuccessfully to limit the development of homeless services in the area and disperse them throughout the city. Many advocates of the poor did not see the policy of containment as ideal, but it was preferable to the complete displacement of these residents (Goetz, 1992).

However, the policy of containment had contradictory tendencies that sowed the seeds of later attempts to dismantle it. First, as Goetz (1992) points out, it became very difficult to contain a rising population of homeless people, whose spillover into the central business district threatened the value of investments there. In the late 1980s and early 1990s, the homeless street population grew dramatically in the Skid Row area, to the frustration of local businesses (Wolch and Dear, 1993; Spivack, 1998). The severe shortage of shelters contributed to rising numbers of homeless people living on the street. To resolve that issue - and as a result of a legal battle - the Los Angeles Homeless Services Authority (LAHSA) was developed in 1993 to administer federal funds for homeless shelters and other services (Spivack, 1998:10). Although LAHSA has 
attempted to disperse services, NIMBY sentiments in nearby cities ensured that a disproportionate level of homeless services, themselves increasingly unable to serve the growing homeless population, would become entrenched in Downtown (Law, 2001). The policy of containment thus created a concentrated and growing constituency of lowincome residents of SROs, homeless people and service providers that has helped to protect it from further threat of displacement.

There was also a second contradictory tendency to the policy of containment. By devaluing land in the Skid Row area, the policy created financial incentives for developers later to invest and redevelop it, especially in proximity to already-redeveloped areas of Downtown, such as Bunker Hill - the complete antipode to Skid Row and the site of the earliest displacements of poor people from the CBD (Barney, 2007). The promise of reaping large profits from redeveloping cheap land and property in Skid Row coupled with the further appreciating value of existing Downtown businesses and property, lured investors into the area. The forces of upgrading were officially unleashed in 1999 - relatively late compared to places like New York and Chicago - with the passage of the Adaptive Reuse bylaw, which permitted the conversion of vacant commercial structures into residential buildings (City News Wire, 2004). Investors, such as the Los Angeles County Economic Development Corporation, oversaw the creation of thousands of units of housing: mainly lofts, condominiums, and luxury apartments (Sterngold, 2003). Recent revitalization trends in Downtown proved to be a profitable investment; in the previous decade, apartments were sold for US \$4-8 per square foot. By 2004, they cost anywhere from US \$50-70 (Flanigan, 2004).

\section{Deconcentrating poverty through housing/service displacement}

The concentration and containment of the homeless on Skid Row began to yield by the late 1990s to deconcentration and displacement pressures. Here, we focus on displacement of housing and services; next we tackle a second mechanism of poverty deconcentration: displacement by police action and harassment. In 1999, city zoning officials identified 11 Downtown residential hotels in Skid Row as public nuisances. Hotel owners were ordered to improve conditions with renovations and install security cameras in response to community complaints on crime. In 2003, the city council demanded the city to 'begin vigorously enforcing orders to crack down on drug dealing and prostitution, clear trash and properly dispose of needles and syringes in and near Skid Row hotels, bars, and liquor stores' (Rivera, 2003a). While some of these complaints represented efforts by tenants and their allies to improve the buildings, pressures on hotels to undergo costly renovations also served business and political interests to close them. According to Frank A. Weiser, the Travelers Hotel's attorney, 'Nobody has ever shown an actual case of someone being arrested in the hotel or crime originating from the hotel. I think there is a political agenda because these hotels cater to the homeless, and because of downtown development, they don't want the homeless or hotels around anymore' (Rivera, 2003a). Similarly, the San Julian Hotel was demolished in 2003 to make space for a children's park as a result of a public nuisance ordinance and amidst complaints of drug activities (Rivera, 2003b). The Downtown Women's Center (DWC), which provided low-cost housing and services to women living in Skid Row since the late 1970s, was also slated for relocation in 2008 because of revitalization efforts (Vincent, 2004). ${ }^{3}$ Owners of SRO hotels seeking to profit from Downtown development projects have also practiced illegal evictions of tenants - using the so-called '28-day shuffle' in which residents are moved every month within the hotel so they can never claim the legal protections from eviction provided to tenants (Stewart, 2004).

3 Recently, a developer bought a parking lot located near the center with plans to construct new stores in the area, thus the relocating to the heart of Skid Row. 
The CCEA had long promoted 'the de-concentration away from Downtown' for services for low-income residents, and the more powerful CCA joined them in 2002 (CCA, 2002; Barney, 2007; Blasi et al., 2007). As a CCEA staff person for the organization explained:

It's frustrating for the industry to see somebody out there who's half naked, could be bleeding... no shoes on, screaming obscenities to people in the middle of the street and clearly crazy and in need of help!... We definitely always push for spreading [services] out ... We always ask for [law] enforcement ... Revitalizing downtown, 24/7, that's what it [CCEA] plays into.

As this quotation suggests, although CCEA expresses concern for the homeless, its twin policy agenda of relocating services away from Downtown and increasing law enforcement is integral to Downtown redevelopment interests.

In response to lobbying from business groups such as the CCEA, and responding to homeless advocates' concerns about the need for more social services, County supervisors adopted a US \$100 million deconcentrated regional plan in 2006 to develop shelters and provide additional assistance and services to homeless people (Streisand, 2006). Rather than locating new shelters and drop-in service centers in Skid Row, they planned to locate them away from Downtown, in neighboring cities, such as El Monte, Glendale, Long Beach, Pasadena, and West Covina (Chou and Mezza, 2006). The creation of new shelters outside of Downtown has been met with substantial community opposition in more suburban locales however. Already, officials in West Covina and El Monte have vocally opposed efforts to locate new shelters in their cities (Cleeland, 2006), showing once again how difficult it is to introduce a 'social mix' into middle/ upper class neighborhoods - that is, the mirror image of poverty deconcentration and gentrification (Slater, 2006a).

\section{Deconcentrating poverty through police action}

Simultaneous to the displacement of services and housing was the escalating harassment of the homeless by the police, with greater arrests leading to a de facto displacement through eviction and imprisonment. As in many other cities, 'zero tolerance' policing strategies have spread to Los Angeles (Parenti, 1999; DeVerteuil, 2006). LA's Police Chief William Bratton, hired in 2002, built his career by promoting these types of policing strategies, which are based on the 'broken windows' theory of crime. According to this theory, advanced by criminologists James Q. Wilson and George Kelling, violence can only be suppressed if the 'quality of life' offenses that encourage social disorder (e.g. painting graffitti or breaking windows) are punished swiftly and eliminated. After bringing 'zero tolerance' policing to New York as the City's Police Commissioner, Bratton was hired by private security corporations and then toured six continents as an 'expert' crime consultant for police and security forces (Smith, 2001). According to several LAPD officers, however, 'Before Bratton arrived, we had the same policy. Bratton just added his philosophy to it' (personal interview).

In addition to hiring Bratton, the city of Los Angeles hired a group coordinated by George Kelling to develop the Eastside Detail program for the city. Eastside Detail is composed of 16 officers and a sergeant whose work focuses on resolving problems associated with Skid Row's homeless population (Boyarsky, 2003). As a member of the LA Community Action Network (LACAN) put it, 'They brought in this whole team just to focus on getting the homeless people off the street'. In total, Kelling and associates were paid US $\$ 556,000$ in consultation fees for helping the city to design, promote and implement the 'Safer City Initiative' (Blasi et al., 2007).

The Safer City Initiative (hereafter, SCI) was first discussed in a 2002 LAPD internal memorandum tellingly entitled 'Homeless Reduction Strategies'. The memo recommended the hiring of additional officers to police the Skid Row area, the passage 
of various new ordinances prohibiting camping, urination, and defecation in public areas, as well as the dispersement of social services from the area. Planning meetings for SCI involved police officers, Downtown business representatives, politicians, as well as representatives of faith-based groups, Shelter Partnership and People Assisting the Homeless (Office of Mayor James K. Hahn, 2004; Blasi et al., 2007). The initiative purportedly aims to 'prevent violent crime, alleviate fear, improve the quality of life in the city's residential neighborhoods, parks, and business districts, and create and support a climate in which local economic development continues to flourish' (Office of Mayor James K. Hahn, 2004).

Under Bratton's leadership, the LAPD began to enforce long-standing 'public nuisance' laws and ordinances against sleeping on public sidewalks with new vigor, leading to a surge in arrests of homeless people. Beginning in 2003, the Los Angeles City Council passed a series of new anti-homeless ordinances as part of the SCI, including a new ordinance making it illegal to urinate or defecate in public (Garrison, 2003). As the police captain of the Central division of the LAPD explained in a personal interview with the authors, "we championed this "no urination/defecation" ordinance and the city council passed that, and that's what the business community wanted'. By 2004, the city passed several other anti-homeless ordinances: one that prohibits any person from parking their car on any city street, lot, or beaches throughout the day and night and another that restricts people from staying or loitering within the boundaries of a public library at night. According to members of LACAN, 'This is just an effort to make it criminal to be poor' (Orlov, 2003). In 2004, Los Angeles was ranked by the National Coalition for the Homeless as one of the meanest cities due to its criminalization of the homeless (National Coalition for the Homeless, 2004). In 2006, California legislators passed a new law increasing the penalties for drug trafficking within 1,000 feet of a drug treatment center or homeless shelter. This measure, supported by Los Angeles politicians concerned about restoring 'law and order' within Skid Row, makes homeless drug offenders more vulnerable to harsher penalties than drug offenders residing in affluent communities with relatively few treatment centers (Vogel, 2007).

Under Bratton's leadership, LAPD officers engaged in a new round of police sweeps of homeless encampments and arrests of the indigent. In one such sweep in 2002, LAPD arrested almost 200 people for sleeping or lying on sidewalks (Spalding, 2003). Between January 2003 and March 2004, a total of 1,473 arrests were made for this crime. According to several LAPD officers, they are simply enforcing the law and responding to complaints about the homeless from a 'broad spectrum' of people who live and work in the Skid Row area, including some of the non-profit organizations providing services to this population:

Some missions and shelters that absolutely do not want homeless people (or, a certain type of homeless people) hanging out on their sidewalks. The people inside the shelters and missions are seeking help for ... addiction to drugs or alcoholism ... Once you step right out those doors on that sidewalk, there's drugs and alcohol readily available for you. So the shelters don't even want the 'shelter resistant' homeless in front of their places ... You've got huge business concerns down here ... It's their people coming to work every day ... We got, over in the loft district, the residents there, the artists ... they complain about it. Because of the people establishing domicile up against their building ... and they make a mess.

Arrests in the Skid Row area escalated after an additional 50 police officers were reassigned to the area in September 2006, increasing the total number of active field officers in the city's Central Division area to 350 (Khalil, 2006). Between August 2006 and June 2007, a total of 10,342 citations were written, including 5,070 felony arrests, in an area with a total population of under 10,000. Research on a sample of Skid Row area citations revealed that, '. . all other things being equal, the odds of a person receiving a pedestrian citation are between 48 and 69 times greater in Skid Row than in the rest of the City'. About half of all Skid Row arrests are for drug possession or sales. Drug sale 
arrests are mainly made through 'buy/bust' stings by undercover officers targeting addicts and involving small quantities of drugs; felony drug sales convictions render those arrested ineligible for rehabilitation service alternatives to prison and felons are barred from various kinds of housing and public assistance after completing their sentences. The Streets or Services program, adopted as part of SCI, was supposed to provide those arrested for misdemeanor crimes an option of completing a 21-day rehabilitation program instead of facing fines or sentences. However, the program was grossly underfunded and apparently ineffective. Out of 303 people referred to the program in the first two months of 2007, only 101 were admitted, and a mere 7 people graduated (Blasi et al., 2007). Quantitative analyses further reveal that the difference in recent declines in the rate of serious crimes within the Skid Row area and other central city areas of Los Angeles were not statistically significant, except for robberies, suggesting that implementation of SCI, has not been effective in reducing serious crime - contrary to the claims of those championing the initiative (Blasi and Stuart, 2008).

As in other cities, roll-out neoliberalism involves public-private partnerships. To assist public police officers and street services, Downtown's Business Improvement Districts $(B I D s)^{4}$ administer color-coordinated clean-up crews and safety officers. In Downtown, there are over 100 private security guards, financed with the 8 Downtown BIDs' US \$12 million budget. LAPD officers praise guards for providing extra 'eyes and ears' to the force, which they claim is under-staffed (Community Connection, 2005). According to LAPD officers, 'One BID, in the last year, handled 85,000 calls for service. . . . Now, we probably wouldn't have handled all of those, but a number of those calls would have been handled by us and we just don't have the officers to do that'.

The CCEA's safety guards and clean-up crew are known as the 'red shirts team'. Subcontracted through Chrysalis (a non-profit organization designed to transition the unemployed into entry-level jobs), this team includes former parolees, addicts in recovery and formerly homeless residents from Los Angeles (some of whom are training to become police officers). Those who were once at the bottom of the social class hierarchy are now the very forces policing the poor. Safety officers assist the intoxicated, prevent fights, and prevent vehicle break-ins; they also respond to LAPD requests for help in enforcing drug laws and conducting police sweeps. As one safety officer says, 'We use batons, pepper spray, and handcuffs. We can make an arrest depending on the situation. If we see fights, weapons, [or] somebody got stabbed, we'll do an actual arrest and then call PD'. At the same time, safety officers assist LAPD in identifying illegal vendors who sell hot dogs, DVDs, and ice cream. One clean team staff says, 'We assist LAPD in disposing and destroying [property]. Whatever LAPD ask us to do, we assist'. According to LACAN members, guards possess P38 batons, the same ones police officers use, and some carry handguns.

For many Downtown businesses, security guards have improved street life in Skid Row. Carol Schatz, President and CEO of the Central City Association, says, 'All you have to do is walk down the street and you can see the change we've brought about. There's not one person who could say the area hasn't improved because of BIDs' (Wan and Ailworth, 2004: B1). However, homeless people and their advocates question the accountability of private security officers and the legality of their actions. As Alice Callahan, who directs a family service center in Skid Row points out, 'Public sidewalks are being patrolled by private security guards ... That's scary. These guards are only answerable to private organizations' (Wan and Ailworth, 2004: B1).

The LAPD, along with other city officials, also investigated reports of police and hospitals in other areas 'dumping' recently discharged prisoners and hospital patients in Skid Row, prompting the passage of a new law in 2006 making it illegal for hospitals to dump homeless patients across city boundaries without authorization. By November,

4 Business Improvement Districts establish voluntary taxes for local businesses in order to provide extra services that the municipality does not provide. 
2006, the city attorney and other legal organizations were preparing law suits to end these and other types of dumping practices contributing to the concentration of homeless people in Skid Row (Winton, 2006).

\section{Resistance and inertia to the deconcentration of poverty}

The very concentration of housing and services for low-income and homeless people within Skid Row has encouraged various forms of resistance to arise as it has facilitated their organization and collective action. Along with protests and lobbying, low-income residents of the Skid Row area have resisted their displacement through a series of lawsuits. In 2004, residents at the Bristol Hotel were illegally evicted without warning by the owner Adolfo Suaya, who hoped to renovate the building as part of Downtown's renaissance. Since 1985, the CRA held an agreement with the former Bristol Hotel owner to maintain the building as affordable units until 2015. Nevertheless, the CRA initially agreed with Suaya's plans. Then, under pressure from local residents and negative publicity, the CRA promised to uphold the 1985 agreement. In response to the evictions, former residents, with the assistance of the Legal Aid Foundation, sued the hotel for the damages associated with their wrongful eviction. Barbara Schultz of Legal Aid comments, 'You had a population of folks who didn't know they had any choice but to leave when they were told to leave. They didn't know they had any rights as tenants' (Stewart, 2004).

The Community Action Network and other advocates of affordable housing also lobbied city officials to create a moratorium on the conversion of SRO housing units into condominiums or luxury apartments. In 2006, the City Council responded by passing a temporary moratorium on these conversions, while the Community Redevelopment Agency issued new guidelines and called for a 55-year commitment by 'transient' hotels to offer 'affordable' housing units (Mailander, 2006). In 2008, the moratorium became permanent and wider ranging, protecting close to 19,000 units in and around Downtown, an important victory for low-income residents (LA CAN, 2008).

Low-income residents, with the help of community organizations and civil rights attorneys filed a series of lawsuits against their unlawful treatment by private and public security officers. ${ }^{5}$ In 1999, the American Civil Liberties Union (ACLU) sued four BIDs when their security guards assaulted and illegally imprisoned the homeless during a police sweep. Two BIDs then settled the lawsuit 'agreeing not to photograph, interrogate, search or order homeless residents to move along' (Wan and Ailworth, 2004: B1). In 2000, a security guard was physically attacked by co-workers after he criticized them for violence towards the homeless. The security guard, Wilford Johnson, settled US $\$ 595,000$ after suing the BID. In 2004, guards in the Fashion District were charged for extortion with illegal vendors, earning at least US $\$ 50$ a day (Wan and Ailworth, 2004).

In 2004, law enforcement conducted a police sweep resulting in the arrest of 21 people for social security fraud. Dessie Robinson - a disabled woman - and several others suffering from physical and mental illnesses were arrested at gunpoint. According to Robinson's lawyer, the agents 'acted like they were on some kind of glorified mission, like they were arresting terrorists from Al Qaeda instead of frightened physically and mentally disabled people, none of whom reasonably could be perceived as posing a threat to anyone' (Rosenzweig, 2004). Although most of the individuals resolved situations with the Social Security Administration by making reductions on future checks, law enforcement acted with full power to arrest the individuals. Robinson and her lawyer claim the arrest was based on racial discrimination since all 21 individuals

5 California law restricts private security guards from using police power; like other private citizens, they are only allowed to 'observe and report'. Guards are only authorized to make a citizen's arrest, detain, and pat down suspects (Community Connection, 2005: 5). 
were African- Americans (Rosenzweig, 2004). Even before Bratton's arrival, LAPD was accused of 'excessive force' and pledged to reform itself (Winton, 2004).

In 2003, the ACLU sued the city for its enforcement of a local ordinance, adopted in 1900, banning people from sleeping on public sidewalks, claiming that it was cruel and unusual punishment given the shortage of shelter beds. In 2006, the US Circuit Court of Appeals ruled in favor of the ACLU. The City Council appealed the decision, rejecting a legal settlement with the ACLU that would have allowed the homeless to sleep on the sidewalks between 9pm and 6am. City politicians, business leaders (including the Central City Association), and residents opposed the proposed settlement, claiming it would attract more homeless into Skid Row. Even so, the city issued temporary guidelines for enforcing the ordinance only during daytime hours (Hymon and Winton, 2006).

Community groups also put pressure on Bratton to curtail the enforcement of antihomeless ordinances by inviting him to discuss the issue with community members. At the event, homeless residents criticized these ordinances and their enforcement as inhumane given the lack of available shelter. Community activists also held press conferences in response to reports of police harassment of the homeless, including their arrest for the possession of 'stolen milkcrates' that were used for seating or storing personal property. When 50 additional police officers were assigned to the Skid Row area, community activists questioned the policy at the mayor's news conference. Alice Callahan, a service provider, claimed, 'It's about real estate ... It's about purifying the public sidewalks so the people moving into these lofts Downtown won't feel afraid'. Thoman Jenkins, a homeless resident commented, 'The money used to pay for the massive police deployment could be better used to build another low-income shelter' (cited in Khalil, 2006). Defense attorneys publicized their own complaints with the 'law and order' crackdown on homeless drug addicts in Skid Row, as cases formerly prosecuted as drug possession cases began to be prosecuted as drug sales cases, leading to more severe prison sentences (Hong, 2007).

These active and prominent acts of resistance from below also combine with NIMBYism described above as well as larger forces of inertia and weak-center gentrification that are limiting poverty deconcentration of Downtown Los Angeles more generally, and Skid Row more particularly. By early 2008, the Downtown real estate market was floundering admist over-building, credit crunch and a national slowdown. The US $\$ 600,000$ condos now appeared rather overpriced considering that for a similar amount, a house with a backyard could be purchased within easy commuting distance and without the sharp social divisions still so apparent in Downtown (DiMassa, 2008; Hong, 2008).

\section{Discussion}

This case study holds several key empirical and theoretical implications about the struggles over poverty deconcentration under conditions of roll-out neoliberalism and weak-center gentrification. First, in empirical terms, it is important to note that the dismantlement of Skid Row has begun but remains far from complete. Most attention has been focused on displacing the literally homeless as well as SRO hotels on the periphery of Skid Row. A count of homeless people living on the street in Skid Row, taken in January 2007, showed that their numbers declined 35\% since the same time last year from 1,345 to 875 (Khalil and DiMassa, 2007). Otherwise, resistance and inertia has so far worked against a successful frontal assault; the vast majority of homeless services remain, with no plans to relocate any time soon. Moreover, homeless people continue to survive in Downtown (and increasingly nearby) despite horrendous pressures to evict and displace them all - evidence that established homeless geographies are more persistent than the more 'revanchist' understanding of deconcentration, gentrification, 
and neoliberalization based mainly on case studies of strong-center cities suggests (DeVerteuil et al., 2009). This also speaks to the relatively late start and slowing nature of gentrification in Downtown Los Angeles, at least for the time being, rather than a 'relentless march' (Slater et al., 2004).

As is characteristic of neoliberal urban policies and local growth coalitions, the ongoing deconcentration of Skid Row has involved strategic alliances among the local state (city and County officials and police), the private sector (in the form of business associations and BIDs) and/or non-profit sectors (well-established service agencies who want to rid Skid Row of more marginalized groups, such as drug addicts and former felons, viewed as 'undeserving' or 'shelter resistant'). Simply removing both the literal homeless and the homeless service providers from Skid Row would be devastating, given that the neighborhood acts as a key station of last resort for homeless survival Countywide (DeVerteuil, 2006). The dismantlement of Skid Row risks displacing a crucial reservoir of cheap housing and support systems for the most vulnerable of populations. As more homeless people have left Skid Row, shelters in the surrounding communities have been unable or unwilling to meet the growing demands for emergency beds (Khalil and DiMassa, 2007).

This case study also illustrates the contradictions inherent in 'spatial fixes' for capitalist accumulation. As Harvey (1985: 61) warns, 'Although capital can buy back time for itself out of the space it conquers, it cannot do so indefinitely nor avoid spreading the conditions for crisis formation over ever-wider spaces'. When capital investment in Downtown Los Angeles expanded in the 1970s, Skid Row initially acted as a convenient pool for society's outcasts, and over time this socio-spatial arrangement became entrenched with the policy of containment, protecting and attracting Downtown investments in other areas. However, this very entrenchment created a series of contradictory crises, as it established a constituency of SRO residents, street people and homeless service providers that acted as a bulwark against overt incursions. When homelessness exploded in the 1980s, the overflow from Skid Row threatened to depreciate the values of surrounding Downtown properties and businesses. The policy response has been to contain the problem more severely, but as interest in speculative development in Downtown increased, policies shifted to outright displacement and deconcentration. The land on the edge of Skid Row, so long devalued and ignored, now appears both as a potentially profitable investment and as a growing threat to existing Downtown investments. Thus, the policy of containment, adopted in response to Downtown investors' earlier search for a 'spatial fix' for capital accumulation and homeless advocates' concerns for the poor, generated two contradictory impulses in subsequent years: elites' efforts to deconcentrate the homeless and expand Downtown gentrification - and on the other hand - opposition to that strategy.

\section{Conclusion}

Poverty deconcentration threatens to disrupt the existing - and in some cases longstanding - geography of services and survival strategies for vulnerable populations within American cities, and to reduce their capacity to mobilize as a group. This is not to say that Skid Row Los Angeles is an ideal environment for the homeless, for it is clearly not; rather, it is to say that is (unfortunately) an essential fixture in the business of homeless survival, given the great difficulties in (equitably) dispersing services to areas that have none at all.

We have argued here that the processes of poverty deconcentration and gentrification within 'weak-centered' cities differs from those occurring within 'strong-center' cities. Our case study of Downtown Los Angeles shows that there was stubborn resistance to its gentrification and efforts to disperse poor people away from it. This resistance emerged among the poor people and their allies concentrated within Downtown, as well as from 
NIMBYism in outlying neighborhoods and cities. Similar sorts of resistance to poverty deconcentration/gentrification also occurs within 'strong-center' urban areas. However, we would expect that the push for poverty deconcentration to be generally stronger and resistance to it to be generally weaker within 'strong-center' cities than 'weak-center' ones, since local capital is likely to be more unified, powerful, and geographically concentrated in the former cities than in the latter ones. The weakness of capital in the central city area of 'weak-centered' cities also enables homeless and other poor people to become geographically concentrated there, encouraging greater resistance from below to poverty deconcentration. Comparative studies of the processes of gentrification/ poverty deconcentration in weak-centered and strong-centered cities are needed to examine these hypotheses more systematically than is possible through a single case study. Greater research is also needed on weak-center gentrification in other polycentric urban regions such as Phoenix, Houston and Atlanta, as well as its implications for homeless service geographies.

The role of race relations and racism in shaping the processes of gentrification and poverty deconcentration within such cities also warrants more attention. In the case of Downtown Los Angeles, most of those displaced are African-American, while most gentrifiers are white (and possibly Asian). This state of affairs is conveniently sidestepped in official accounts of Downtown LA's upgrading, although racialized conceptions of criminality and poverty are often implicit in the rhetoric surrounding efforts to disperse homeless services and to enforce 'anti-homeless' ordinances. The racial dynamics involved in these processes are however not so easily avoided when one moves to street level (Wolch, 2008). In other polycentric regions in Southwest USA, Latinos have been the main target of poverty deconcentration. Exploring the ways that race and class interact to shape the experiences of poverty deconcentration, as well as the rhetoric used to justify or oppose it, would be particularly fruitful lines for future research.

Ellen Reese (ellen.reese@ucr.edu), Department of Sociology, University of California, Riverside, Riverside, CA 92521-0419, USA, Geoffrey DeVerteuil

(G.P.DeVerteuil@soton.ac.uk), School of Geography, University of Southampton, Highfield Campus, Southampton S017 1BJ, UK and Leanne Thach (leanne.thach@gmail.com), 16911 Bixby St. \# 37, San Diego, CA 92127, USA.

\section{References}

Barney, P. (2007) A crisp, new $\$ 20$ bill/a nickel taken: 'revitalization', gentrification and displacement in Los Angeles' Skid Row. Master's thesis, Occidential College, Los Angeles, CA.

Blasi, G. and the UCLA School of Law Fact Investigation Clinic (2007) Policing Our way Out of homelessness? The first year of the safer cities initiative on Skid Row. Unpublished manuscript, 24 September.

Blasi, G. and F. Stuart (2008) Has the safer cities initiative in Skid Row reduced serious crime? Research Report, School of Law and Department of Sociology, UCLA.

Boyarsky, B. (2003) Homeless, a cause liberal L.A. runs from. Los Angeles Times 2 March, B1.
Burawoy, M. (1991) The extended case method. In M. Burawoy (ed.), Ethnography unbound: power and resistance in the modern metropolis, University of California Press, Berkeley.

Center City Association (CCA) (2002) Downtown's human tragedy: it's not acceptable anymore. Center City Association, Los Angeles.

Chou, E. and S. Mezza (2006) Cities resist shelter plan. San Gabriel Valley Tribune 7 April, A1.

City News Wire (2004) Downtown mission. 1 June, A1.

Cleeland, N. (2006) Low pay, high rent, wit's end. Los Angeles Times 24 October, B3. 
Community Connection (2005) Strange bedfellows: LAPD and B.I.D. security. Community Connection Newsletter of the Los Angeles Community Action Network, January/February [WWW document]. URL http://www.cangress.org/archivepublications/CommunityConnection3.pdf (accessed 28 February 2006).

Community Connection (2008) Historic protections for LA's housings of last resort will help prevent gentrification city-wide. Community Connection Newsletter of the Los Angeles Community Action Network, July/August [WWW document]. URL http://www.cangress.org/archivepublications/connection-july-august.pdf (accessed 15 October 2008).

Crump, J. (2002) Deconcentration by demolition: public housing, poverty, and urban policy. Environment and Planning $D$ 20.5, 581-96.

Davis, M. (1990) City of Quartz. Verso, London.

Dear, M. and J. Wolch (1987) Landscapes of despair. Princeton University Press, Princeton University.

DeVerteuil, G. (2005) The relationship between government assistance and housing outcomes among extremely low-income individuals. Housing Studies 20.3, 383-99.

DeVerteuil, G. (2006) The local state and homeless shelters: beyond revanchism? Cities 23.2, 109-20.

DeVerteuil, G., J. May and J. Von Mahs (2009) Complexity not collapse: recasting the geographies of homelessness in the 'punitive' age. Progress in Human Geography 33.5, 646-66.

DiMassa, C. (2008) LA's Grand Avenue project snags on loans. Los Angeles Times 29 April, B1.

Flanigan, J. (2004) Downtown cultural buildup is driving L.A. Los Angeles Times 25 July, B1.

Garrison, J. (2003) Ordinance bans public urination. Los Angeles Times 23 October, B1.

George, A. (1979) Case studies and theory development: the method of structured, focused comparisons. In P. Gordon (ed.), Diplomacy: new approaches in history, theory, and policy, Free Press, New York.

Goetz, E. (1992) Land use and homeless policy in Los Angeles. International Journal of Urban and Regional Research 16.4, 540-54.
Hackworth, J. (2003) Public housing and the rescaling of regulation in the USA. Environment and Planning A 35.3, 531-49.

Hackworth, J. (2005) Emergent urban forms, or emergent post-modernisms? A comparison of large U.S. metropolitan areas. Urban Geography 26.6, 484-519.

Hammel, D. (2006) Public housing Chicago style: transformation or elimination? In R. Greene (ed), Chicago's geographies: metropolis for the $21^{\text {st }}$ century, Association of American Geographers, Washington DC.

Hannigan, J. (1995) A new urbanization? Current Sociology 43.1. 201-5.

Harvey, D. (1982) The limits to capital. University of Chicago Press, Chicago.

Harvey, D. (1985a) The urbanization of capital: studies in the history and theory of capitalist urbanization. The John Hopkins University Press, Baltimore, MD.

Harvey, D. (1985b) Consciousness and the urban experience: studies in the history and theory of capitalist urbanization. The John Hopkins University Press, Baltimore, MD.

Harvey, D. (2001 [1981]) The spatial fix: Hegel, Von Thunen, and Marx in Spaces of capital: towards a critical geography. Routledge, New York.

Hong, P.Y. (2007) Drug crackdown on Skid Row called harmful. Los Angeles Times 6 February, B1.

Hong, P.Y. (2008) Downtown not the center of it all. Los Angeles Times 13 March, B1.

Hymon, S. and R. Winton (2006) The state. Attempt to settle skid row suit fails. Los Angeles Times 21 September, B1.

Jessop, B. (2002) Liberalism, neoliberalism, and urban governance: a state-theoretical perspective. Antipode 34.3, 452-72.

Keil, R. (1998) Los Angeles. Wiley Press, New York.

Khalil, A. (2006) Skid Row police campaign debuts. Los Angeles Times 25 September, B1.

Khalil, A. and C.M. DiMassa (2007) Rousting of Skid Row homeless puts strain on surrounding areas. Los Angeles Times 1 February, B1.

Law, R. (2001) 'Not in my city': local governments and homelessness policies in the Los Angeles metropolitan region. Environment and Planning C 19.6, 791-815. 
Lee, B.A. and T. Price-Spratlen (2004) The geography of homelessness in American communities: concentration or dispersion? City and Community 3.1, 3-27.

Los Angeles Homeless Services Authority (2006) 2005 Greater Los Angeles homeless count. Applied Survey Research, Watsonville, CA.

Mailander, J. (2006) Gentrification: Downtown's bipolar housing policy. Los Angeles Times 30 July, B1.

Mitchell, D. (2003) The right to the city: social justice and the fight for public space. The Guilford Press, New York and London.

National Coalition for the Homeless (2004) Illegal to be homeless: the criminalization of homelessness in the United States. National Coalition for the Homeless, Washington DC.

National Law Center on Homelessness and Poverty (2006) A dream denied: the criminalization of homelessness in U.S. cities. National Law Center on Homelessness and Poverty, Washington DC.

National Low Income Housing Coalition (2006) Out of reach. National Low Income Housing Coalition, Washington DC.

Newman, J. and E. Wyly (2006) The right to stay put, revisited: gentrification and resistance to displacement in New York City. Urban Studies 43.1, 23-57.

Office of Mayor James K. Hahn (2004) Mayor Hahn, Chief Bratton Announce Successful Crackdown on the Production and Sale of Illegal Documents in Macarthur Park 9 November [WWW document]. URL http://www.lacity.org/ mayor/oldpresss/mayormyrpress27425284 11232004.pdf (accessed 30 May 2005).

Orlov, R. (2003) Activists say law targets the homeless. The Daily News of Los Angeles 12 December, B1.

Parenti, C. (1999) Lockdown America: police and prisons in the age of crisis. Verso, London.

Peck, J. (2001) Workfare states. Guilford Press, New York.

Peck, J. and A. Tickell (2002) Neoliberalizing space. Antipode 34.3, 380-404.

Rivera, C. (2003a) Los Angeles residents protest state of Skid Row. Los Angeles Times 29 October, B3.

Rivera, C. (2003b) It's checkout time for one old hotel on L.A.'s Skid Row. Los Angeles Times 29 November, B3.
Rosenzweig, D. (2004) Public defenders decry aid recipients' arrests. Los Angeles Times 4 September, B1.

Rymer, R. (2001) The rules of the Row. Mother Jones March-April, 38-45.

Shaw, K. (2005) Local limits to gentrification. In R. Atkinson and G. Bridge (eds.), Gentrification in a global context: the new urban colonialism, Routledge, London.

Slater, T. (2006a) The eviction of critical perspectives from gentrification research. International Journal of Urban and Regional Research 30.4, 737-57.

Slater, T. (2006b) The downside of upscale. Los Angeles Times 30 July, A24.

Slater, T., W. Curran and L. Lees (2004) Guest editorial on gentrification research. Environment and Planning A 36.7, 1141-50.

Smith, N. (2001) Global social cleansing: postliberal revanchism and the export of zero tolerance. Social Justice 28.3, 68-74.

Smith, N. (2002) New globalism, new urbanism: gentrification as global urban strategy. In N. Brenner and N. Theodore (eds.), Spaces of neoliberalism: urban restructuring in North America and Western Europe, Blackwell Publishing, London.

Soja, E. (2000) Postmetropolis: critical studies of cities and regions. Basil Blackwell Press, Oxford.

Spalding, P. (2003) The complexity of homelessness. The Daily Trojan 3 September [WWW document]. URL http://dailytrojan.com/ (accessed 15 January 2006).

Spivack, D. (1998) CRA's role in the history and development of Skid Row in Los Angeles. History of Skid Row Series, Paper 1, 1-17.

Sterngold, J. (2003) New life for old area of L.A.: Downtown revival in full swing. The San Francisco Chronicle 27 October, A5.

Stewart, J. (2004) Hotel's past is clouding its future: Some worry a plan to turn Bristol from low-cost housing to boutique inn comes at expense of the poor. Los Angeles Times 30 June, B1.

Streisand, B. (2006) Homeless sprawl. US News and World Report 18 December, ER: 50-4.

Vincent, R. (2004) Parking lot sold for $\$ 30$ million: developer Astani Enterprises plans to build condominiums and shops on the Downtown L.A. parcel. Los Angeles Times 14 September, C1. 
Vogel, N. (2007) New laws will affect millions. Los Angeles Times 1 January, A1.

Wan, W. and E. Ailworth (2004) Flak over downtown security guards. Los Angeles Times 8 June, B1.

Wilson, D. (2006) The growing socio-spatial polarization in Chicago. In R. Greene (ed.), Chicago's geographies: metropolis for the $21^{\text {st }}$ century, Association of American Geographers, Washington DC.

Wilson, W. J. (1987) The truly disadvantaged. University of Chicago Press, Chicago.

Winton, R. (2004) Bratton wants bigger LAPD. Los Angeles Times 29 October, B1.

Winton, R. (2006). Delgadillo to sue hospitals that dump patients on skid row. Los Angeles Times November 8, B1.
Wolch, J. (2008) Intransigent LA. Geoforum 39.3, 543-5.

Wolch, J. and M. Dear (1993) Malign neglect: homelessness in an American city. Jossey-Bass, San Francisco.

Wyly, E. and D. Hammel (1999) Islands of decay in seas of renewal: Housing policy and the resurgence of gentrification. Housing Policy Debate 10.4, 711-71.

Wyly, E. and D. Hammel (2005) Mapping neo-liberal American urbanism. In R. Atkinson and G. Bridge (eds.), Gentrification in a global context: the new urban colonialism, Routledge, London.

\section{Résumé}

Cette étude de cas porte sur les efforts entrepris récemment pour déconcentrer la pauvreté dans le quartier de Skid Row à Los Angeles. Elle examine les processus de gentrification d'un 'centre faible' lorsqu'ils s'appliquent à un 'ghetto de populations dépendantes de services', et comble ainsi deux grandes lacunes des recherches antérieures. Elle montre comment les intérêts du gouvernement, des entreprises et de l'urbanisme se joignent à certains organismes non lucratifs impliqués dans le processus. De plus, elle identifie deux mécanismes clés de la déconcentration de la pauvreté: le déplacement des logements et/ou services, et la criminalisation des habitants à faible revenu. Dans le sillage de Harvey, l'étude préconise que les efforts entrepris sont suscités par des pressions visant à trouver une 'solution spatiale' à l'accumulation de capital en réaménageant le centre-ville. Toutefois, cette démarche a été vivement contestée, illustrant ainsi la vigueur de la résistance à l'encontre de la gentrification et de la déconcentration de la pauvreté dans le cadre d'un modèle urbain à 'centre faible'. 